\title{
PROSES PERALIHAN TANAH ULAYAT MENJADI HAK GUNA USAHA OLEH PT. MUTIARA AGAM KABUPATEN AGAM
}

\author{
Tiara Sumardi \\ Universitas Indonesia \\ Tiarasumardi13@gmail.com
}

\begin{abstract}
Abstrak.Menurut Perda No. 6 Tahun 2008 Pasal 1 ayat 7 Tentang Tanah Ulayat dan Pemanfaatannya, tanah ulayat adalah bidang tanah pusaka beserta sumber daya alam yang ada di atasnya dan di dalamnya diperoleh secara turun temurun merupakan hak masyarakat hukum adat di Provinsi Sumatera Barat. Pasal 28 ayat 1 UUPA, hak guna usaha adalah hak untuk mengusahakan tanah yang dikuasai langsung oleh Negara, dalam jangka waktu sebagaimana tersebut dalam Pasal 29, guna perusahaan pertanian, perikanan, atau peternakan. Kebijakan pengambilalihan tanah terkait dengan pengaturan mengenai proses pengambilan tanah yang dimiliki oleh masyarakat atau individu-individu oleh negara dan individu-individu atau kelompok masyarakat lainnya. Pengambilan tanah tersebut berhubungan dengan penggunaan tanah yang diambil untuk tujuan pembangunan (jalan, perumahan, industri, kawasan perdagangan, dan lain-lain) serta menyangkut pengaturan kembali penggunaan, pemanfaatan, pemilikan dan penguasaan tanah sejalan dengan penatagunaan tanah. Penelitian ini dilakukan terhadap Proses Peralihan Tanah Ulayat Menjadi Hak Guna Usaha Oleh PT. Mutiara Agam di Nagari Tiku Limo Jorong Kecamatan Tanjung Mutiara Kabupaten Agam yang rumusan masalahnya yaitu : 1. Bagaimana Proses peralihan tanah ulayat menjadi hak guna usaha, 2. Apa manfaat yang dapat diperoleh oleh si pemilik tanah ulayat, 3. Bagaimana kedudukan tanah ulayat disaat penggunaan hak guna usaha dan setelah berakhirnya hak guna usaha. Metode penelitian yang digunakan adalah metode pendekatan yuridis empiris. Hasil penelitian memperlihatkan bahwa tanah yang digunakan oleh PT. Mutiara Agam sebagai hak guna usaha dahulunya adalah tanah ulayat nagari dan akan berakhir sampai tanggal 31 desember 2026 mendatang. Tercantum di dalam Keputusan Kepala Badan Pertanahan Nasional Nomor : 14/HGU/1991 tentang Pemberian Hak Guna Usaha Atas Nama PT. Mutiara Agam. Manfaat yang didapat oleh masyarakat nagari Tiku Limo Jorong adalah dengan diberikannya lahan seluas 3.000 hektare oleh PT. Mutiara Agam sebagai kemitraan plasma, yang dikelola oleh masyarakat. Kedudukan tanah saat ini adalah hak guna usaha dan apabila sudah berakhir akan kembali kepada bentuk semula dan akan dilakukan perundingan kembali.
\end{abstract}

Kata kunci : Tanah Ulayat, Hak Guna Usaha, Peralihan

Abstract. The definition of Communal land according to $6^{\text {th }}$ Local Regulation in $1^{\text {st }}$ article $7^{\text {th }}$ verseon 2008 about Communal land and its utilization is a heritage land with the natural resources over and in it, obtained herediterary and also a part of tradition law society rights in West Sumatera Province. Cultivation Rights Land define by $28^{\text {th }}$ article $1^{\text {st }}$ verse in Basic Agrarians Principles is the rights to cultivates the land that directly managed by its state within certain period of timefor agriculture, fishery and farms Incorporates, as it is mentioned in $29^{\text {th }}$ article of the principles. The policy to take over the land ownershipis related withthe regulation of the takingover land process owned by society or individuals by states or individuals or other groups of society. This taking over process has a correlation with the utilization of the land for contruction purpose such as roads, residentials, industries, trading areas etc and also correlates with readjustment of the land utilization, ownership and authorizationin line with land usefulness. This research was done to Mutiara Agam Inc in Nagari Tiku Limo Jorong Tanjung Mutiara District, Agam Regency. The Problems of the research are first, how do the process of taking over communal land into cultivation rights land? Second, what are the benefits of this process for 
the owner of communal land? Third, How do the status of communal land when it tranforms into cultivation rights land and after the agreement end? This research was conducted with juridical empiric method. The result of this research shows that the land utilized by Mutiara Agam Inc as cultivation rights land is used to be communal land owned by society and the agreement will end on December $31^{\text {th }}, 2026$. The agreement was listed in Injuction of the head of National Land Agency number : 14/HGU/1991 about the cultivation right land given to Mutiara Agam Inc. The benefit for the society of Nagari Tiku Limo is the giving of 3000 hectares land by Mutiara Agam Inc as plasm partnership that will be managed by society. The status of the communal land right now is as the cultivation right land and if this agreement ends, the status will be back into the former status after re-negotiation.

Keywords: Communal land, Cultivation rights, Transition.

\section{PENDAHULUAN}

\section{A. Latar Belakang Masalah}

Masalah tanah adalah masalah yang sensitif bagi manusia pada umumnya dan masyarakat Minangkabau khususnya, karena tanah di Minangkabau merupakan salah satu unsur dalam organisasi matrilineal. "Disamping itu bagi orang Minangkabau tanah dianggap sebagai salah satu kriteria yang menentukan martabat seseorang dalam kehidupan nagari. Seseorang yang mempunyai tanah asal dianggap orang asli dalam nagari yang lebih berhak atas kebesaran dalam nagari”.

Tanah merupakan unsur terpenting bagi kehidupan manusia, mereka dapat hidup dan berkembang karena adanya tanah. Dalam konsepsi agama Islam dinyatakan bahwa tanah adalah unsur pembentuk utama manusia. Pada perkembangannya, tanah membiasi banyak fungsi dan kegunaannya baik itu fungsi sosial, ekonomi agama dan politik. Dalam ranah sosial tanah menjadi faktor utama pendukung kehidupan dan kesejahteraan masyarakat, tanpa adanya tanah mustahil kesejahteraan itu akan dicapai, sehingga dalam hal ini konsep hak kepemilikan tanah menentukan susunan kehidupan dalam suatu negara. Fungsi tanah tidak hanya terbatas pada sarana produksi, sosial, politik, budaya saja, tetapi juga menyangkut nilai dan bermakna religius.

Dalam hukum adat, hak penguasaan atas tanah yang tertinggi adalah hak ulayat, yang mengandung 2 unsur yang beraspek hukum keperdataan dan hukum publik. Subyek hak ulayat adalah masyarakat hukum adat, baik teritorial ataupun geneologis, sebagai bentuk bersama para warganya. Tanah ulayat adalah tanah bersama para warga masyarakat hukum adat yang bersangkutan.

Menurut Perda Provinsi Sumatera Barat No. 6 Tahun 2008 Pasal 1 ayat 7 Tentang Tanah Ulayat dan Pemanfaatannya, tanah ulayat adalah bidang tanah pusaka beserta sumber daya alam yang ada di atasnya dan di dalamnya diperoleh secara turun temurun merupakan hak masyarakat hukum adat di Provinsi Sumatera Barat. Dan terdiri dari 4 macam tanah ulayat yang disebutkan pada Pasal 1 ayat 8,9,10,dan 11 yang berbunyi, tanah ulayat nagari adalah tanah ulayat beserta sumber daya alam yang ada diatas dan didalamnya merupakan hak penguasaan oleh ninik mamak kerapatan adat nagari (KAN) dan dimanfaatkan sebesar-besarnya untuk kepentingan masyarakat nagari. Sedangkan pemerintahan nagari bertindak sebagai pihak yang mengatur untuk pemanfaatannya.

Hak ulayat diakui oleh UUPA, tetapi pengakuan itu disertai 2 syarat yaitu mengenai "eksistensinya" dan mengenai pelaksanaannya, hak ulayat diakui "sepanjang menurut kenyataannya masih ada", demikian pasal 3. Di daerah-daerah dimana hak itu tidak ada lagi, tidak akan dihidupkan kembali. Di daerahdaerah dimana tidak pernah ada hak ulayat, tidak akan dilahirkan hak ulayat baru. Pelaksanaan hak ulayat diatur juga di dalam pasal 3. Pelaksanaan hak ulayat harus sedemikian rupa sehingga sesuai dengan kepentingan nasional dan negara, yang berdasarkan atas persatuan bangsa serta tidak boleh bertentangan dengan 
Jurnal Ilmu Sosial dan Pendidikan

http://ejournal.mandalanursa.org/index.php/JISIP/index

Terakreditasi Peringkat 5 (No. SK: 85/M/KPT/2020)

undang-undang dan peraturan-peraturan lain yang lebih tinggi.

Undang-Undang Nomor 5 Tahun 1960 tentang Peraturan Dasar Pokok-Pokok Agraria yang lebih dikenal dengan Undang-Undang Pokok Agraria (UUPA) merupakan unifikasi hukum yang mengatur masalah agraria di Indonesia sejak tahun 1960 sampai saat ini. Dalam Pasal 4 ayat (1) dinyatakan bahwa atas dasar hak menguasai dari negara sebagai yang dimaksud dalam pasal 2 ditentukan adanya macam-macam hak atas permukaan bumi, yang disebut tanah, yang dapat diberikan kepada dan dipunyai oleh orang-orang, baik sendiri maupun bersama dengan orang lain serta badan-badan hukum. Menurut UUPA hak atas tanah juga tidak meliputi pemilikan kekayaan alam yang terkandung di dalam tubuh bumi di bawahnya.

Dinyatakan dalam pasal 8, bahwa pengambilan kekayaan alam yang terkandung dalam bumi, air dan ruang angkasa perlu diatur. Sehubungan dengan ketentuan Pasal 4 ayat (1) di atas, Pasal 16 mengatur lebih lanjut mengenai hak-hak atas tanah yang dapat diberikan dan dipunyai oleh orang-orang atau badan-badan hukum. Hak-hak tersebut adalah :

a.hak milik;

b.hak guna usaha;

c.hak pakai;

d.hak sewa;

e.hak membuka tanah;

f.hak memungut hasil hutan;

Menurut Pasal 28 ayat 1 UUPA, hak guna usaha adalah hak untuk mengusahakan tanah yang dikuasai langsung oleh Negara, dalam jangka waktu sebagaimana tersebut dalam Pasal 29, guna perusahaan pertanian, perikanan, atau peternakan. Pasal 29 menentukan bahwa jangka waktu yang dapat diberikan untuk hak guna usaha paling lama 60 tahun setelah dilakukan perpanjangan. Kalau tidak diberikan perpanjangan, maka jangka waktunya hanya 25 tahun dan untuk perusahaan-perusahaan dengan usaha tertentu dapat diberikan jangka waktu paling lama 35 tahun.

Berdasarkan pengertian hak guna usaha tersebut diatas, maka tanah yang dapat
Vol. 4. No. 4 November 2020

p-ISSN: 2598-9944 e- ISSN: 2656-6753

diperuntukan untuk hak guna usaha adalah tanah yang dikuasai langsung oleh negara, sedangkan tanah yang dikuasai langsung oleh negara sangat terbatas sekali bahkan sudah tidak ada lagi. Tanah yang luas untuk usaha pertanian/perkebunan hanya dikuasai oleh masyarakat hukum adat. Oleh karena itu (selama ini) dilakukanlah penyerahan hak atas tanah oleh masyarakat hukum adat melalui kepala adat setempat kepada negara dengan membayar rekognisi (pengisi adat) sehingga tanah tersebut jatuh menjadi tanah negara dan baru kemudian diberikan kepada perusahaan dengan hak guna usaha.

Penilitian ini dilakukan di Nagari Tiku Limo Jorong, Kecamatan Tanjung Mutiara, Kabupaten Agam. Kabupaten Agam adalah kawasan perbukitan/pegunungan dan pesisir yang didominasi oleh kawasan lindung dengan basis ekonomi pertanian (perkebunan lahan kering dan hortikultura) namun sekaligus adalah kawasan rawan bencana dengan sebaran potensi bahaya tsunami, abrasi, gerakan tanah/longsor dan gempa serta letusan gunung berapi.

Dalam penelitian ini, tanah yang saat ini dipergunakan oleh PT. Mutiara Agam yaitu berstatus hak guna usaha. Tanah yang terletak pada Nagari Tiku Limo Jorong ini dahulunya sebelum diambil alih adalah berstatus tanah ulayat nagari dari Nagari Tiku Limo Jorong. Terletak pada Jorong Ujung Labung, Masang, Masang Timur, Labuhan, Muara Putus, SubangSubang, dan Ujung Labung Timur. Proses ini dimulai pada tahun 1983 dengan penyerahan tanah hanya terjadi antara Nagari Tiku Limo Jorong dan PT. Mutiara Agam. Dengan penggunaan tanah disekitarnya, sebelah utara sebagian besar berupa hutan rawa, sebelah timur sebagian besar berupa hutan rawa,kebun campuran, sawah, kampung, sebelah selatan sebagian besar berupa hutan rawa, perkebunan kelapa sawit, dan sebelah barat sebagian berupa hutan rawa dan belukar. Kemudian barulah perusahaan yang bergerak pada usaha kelapa sawit ini, mendapatkan hak guna usahanya dari tahun 1991. Dengan dikeluarkannya Keputusan Kepala Badan Pertanahan Nasional Nomor : 
14/HGU/1991 tentang Pemberian Hak Guna Usaha Atas Nama PT. Mutiara Agam.

Berdasarkan latar belakang diatas penulis tertarik untuk melakukan penelitian dengan judul "PROSES PERALIHAN TANAH ULAYAT MENJADI HAK GUNA USAHA OLEH PT. MUTIARA AGAM KABUPATEN AGAM"

\section{B. Rumusan Masalah}

Berdasarkan hal-hal yang telah dikemukakan di atas, maka dapat dirumuskan permasalahan pokok dalam penelitian ini sebagai berikut :

1. Bagaimana mekanisme peralihan tanah ulayat menjadi hak guna usaha ?

2. Apa manfaat yang dapat diperoleh oleh si pemilik tanah ulayat?

3. Bagaimana kedudukan tanah ulayat disaat penggunaan hak guna usaha dan setelah berakhirnya hak guna usaha?

\section{METODE PENELITIAN}

Untuk menjawab permasalahan sebagaimana diungkapkan diatas, diperlukan suatu metode agar hasilnya dapat dipertanggung jawabkan validitasnya dalam penelitian ini, metode penelitian yang digunakan dalam penelitian ini adalah yuridis empiris, maksudnya yaitu melihat peraturan perundang-undangan yang berlaku kemudian dikaitkan dengan kenyataan yang ada. Terkait dengan penelitian ini berupaya melihat mekanisme peralihan tanah ulayat menjadi hak guna usaha oleh PT. Mutiara agam di nagari tiku limo jorong kecamatan tanjung mutiara kabupaten agam.

Penelitian ini bersifat deskriptif analisis, yaitu menggambarkan dan menjelaskan apa yang menjadi permasalahan dan kemudian disesuaikan dengan ketentuan atau normanorma hukum yang mengaturnya sebagai landasan dari penelitian ini. Sumber data pada penelitian ini diperoleh dari penelitian perpustakaan dan penelitian lapangan. Untuk jenis datanya terdapat jenis data primer, Data primer yaitu data yang diperoleh langsung dari sumbernya, baik melalui wawancara, observasi maupun laporan dalam bentuk dokumen tidak resmi yang kemudian diolah oleh peneliti. Penulis langsung terjun ke lapangan untuk mendapatkan keterangan dari pihak-pihak terkait dalam hal ini adalah PT. Mutiara agam dan kerapatan adat nagari tiku limo jorong. Kemudian, data sekunder yaitu data yang diperoleh dari dokumen-dokumen resmi, bukubuku yang berhubungan dengan objek penelitian, skripsi, dan peraturan perundangundangan.

\section{HASIL PENELITIAN DAN PEMBAHASAN A. Mekanisme Peralihan Tanah Ulayat Menjadi Hak Guna Usaha}

Pengadaan tanah untuk kepentingan umum dalam perkembangan hukum pertanahan di Indonesia dilakukan dengan cara dan menggunakan lembaga hukum yang pertama, yaitu pencabutan hak-hak atas tanah dan bendabenda yang ada di atasnya. Pencabutan, pembebasan, dan pelepasan hak-hak atas tanah tidak hanya dilakukan oleh pemerintah untuk pembangunan berbagai proyek pemerintah, namun juga diperuntukkan bagi proyek pembangunan untuk kepentingan umum oleh pihak swasta tetapi pelaksanaannya dilakukan dalam bentuk dan cara yang berbeda. Adapun tujuan pembebasan yang dilakukan oleh pihak swasta dipergunakan untuk pembangunan berbagai fasilitas umum yang bersifat komersil misalnya, pembangunan perumahan/real estate, pusat-pusat perbelanjaan/shopping center, pembangunan jalan bebas hambatan, dan lainlain.

Berdasarkan Peraturan Pemerintah Nomor 40 tahun 1996 pasal 4 tentang hak guna usaha, hak guna bangunan, dan hak pakai atas tanah, tanah yang dapat diberikan dengan hak guna usaha adalah :

(1) Tanah yang dapat diberikan dengan Hak Guna Usaha adalah tanah Negara.

(2) Dalam hal tanah yang akan diberikan dengan Hak Guna Usaha itu adalah tanah negara yang merupakan kawasan hutan, maka pemberian Hak Guna Usaha dapat dilakukan setelah tanah yang bersangkutan dikeluarkan dari statusnya sebagai kawasan hutan. 
Jurnal Ilmu Sosial dan Pendidikan

http://ejournal.mandalanursa.org/index.php/JISIP/index

Terakreditasi Peringkat 5 (No. SK: 85/M/KPT/2020)

(3) Pemberian Hak Guna Usaha atas tanah yang telah dikuasai dengan hak tertentu sesuai ketentuan yang berlaku, pelaksanaan ketentuan Hak Guna Usaha tersebut baru dapat dilaksanakan setelah terselesaikannya pelepasan hak tersebut sesuai dengan tata cara yang diatur dalam peraturan perundang-undangan yang berlaku.

(4) Dalam hal di atas tanah yang akan diberikan dengan Hak Guna Usaha itu terdapat tanaman dan/ atau bangunan milik pihak lain yang keberadaannya berdasarkan atas hak yang sah, pemilik bangunan dan tanaman tersebut diberi ganti kerugian yang dibebankan pada pemegang Hak Guna Usaha baru.

(5) Ketentuan lebih lanjut mengenai pemberian ganti rugi sebagaimana dimaksud dalam ayat (4), ditetapkan dengan keputusan Presiden.

Berdasarkan hasil wawancara dengan pihak perwakilan dari PT. Mutiara Agam yaitu bapak Amsurman dt. Nan Kodorajo selaku Asisten CDO (Community Development Officer) PT. Mutiara Agam, menyatakan bahwa tanah yang sekarang ini dipergunakan oleh PT. Mutiara Agam awalnya pada tahun 1983 diserahkan langsung oleh ninik mamak Tiku Limo Jorong kepada pihak PT. Mutiara Agam tanpa campur tangan pemerintah, dikarenakan pada waktu tahun 1985 itu daerah Tiku Limo Jorong merupakan daerah terisolir, dengan surat pernyataan penyerahan tanah ulayat nagari tanggal 19 Agustus 1983. Ninik mamak dan masyarakat mempersilahkan bagi siapa saja yang mau mengelola tanah didaerah tersebut, dengan tujuan dapat memajukan daerah tersebut. Penyerahan tanah ini awalnya seluas 10.000 hektar lalu kemudian berubah menjadi 8.625 hektare. Dan pada tahun 1990 dilakukan pengurusan hak guna usaha PT. Mutiara Agam atas tanah di Nagari Tiku Limo Jorong. Hak guna usaha inipun keluar pada tahun 1991. Pengurusan hak guna usaha ini dilakukan di kantor BPN Pusat, karena apabila luas tanah hak guna usaha lebih dari 1.000 hektare maka dilakukan pengurusannya di kantor BPN pusat. Salah satu keuntungan lainnya yang diperoleh oleh masyarakat Tiku Limo Jorong yaitu
Vol. 4. No. 4 November 2020

p-ISSN: 2598-9944 e- ISSN: 2656-6753

kemudian dibuatkan plasma seluas 3.000 hektare setelah hak guna usaha tersebut keluar. Awalnya tanah ini terletak di jorong Ujung Labung, Masang, Labuhan, Muara Putus, dan Subang-subang, kemudian terjadi pemekaran di Nagari Tiku Limo Jorong ditambah dengan jorong Masang Timur dan Ujung Labung Timur. Selanjutnya berdasarkan hasil wawancara dengan bapak sekretaris Kerapatan Adat Nagari Tiku Limo Jorong, bapak Agusmaidi Sidi Bandaro menyatakan awal penyerahan nya yaitu saat itu Nagari Tiku Limo Jorong mempersilahkan apabila ada yang ingin berinvestasi, dan yang ingin memajukan daerah Tiku Limo Jorong, karena dulu daerah ini merupakan daerah yang terisolir. Di Nagari Tiku Limo Jorong ini hanya mempunyai dua aset, aset sumber daya alam yang bisa dimanfaatkan adalah laut dan tanah yang luas. Dalam pemikiran ninik mamak yang mungkin bisa mengangkat perekonomian masyarakat adalah yang dua tadi, yaitu tanah dan laut. Pada waktu itu sudah ada beberapa kali perusahaanperusahaan lain nya yang datang ke Nagari Tiku Limo Jorong untuk berinvestasi tetapi waktu itu belum ada yang cocok. Nagari Tiku Limo Jorong menyambut baik ketika PT. Mutiara Agam ini ada kesepahaman dengan Nagari Tiku Limo Jorong, sehingga waktu itu juga tidak ada mengurus ke pemerintah daerah, hanya melalui dua pihak saja yaitu antara PT. Mutiara Agam dan Nagari Tiku Limo Jorong. Tanah yang dipergunakan oleh PT. Mutiara Agam ini merupakan tanah ulayat nagari Tiku Limo Jorong, jadi proses pemindahan hak nya, surat pelepasan hak nya dari nagari kepada PT. Mutiara Agam, yang telah diserahkan oleh ninik mamak dengan adanya Surat Pernyataan Penyerahan Tanah Ulayat Nagari tanggal 19 Agustus 1983, dan pelepasan tanah kawasan hutan berdasarkan Surat Keputusan Menteri Kehutanan, tanggal 25 Agustus 1987 No. 258/kpts-II/1987. Pada awal penyerahan tanah tersebut hanya ada izin lokasi dan izin prinsip, lalu barulah pada tahun 1991 hak guna usaha keluar. 
Peralihan tanah ulayat menjadi hak guna usaha di Nagari Tiku Limo Jorong kepada PT. Mutiara Agam ini semakin diperkuat dengan adanya Keputusan Kepala Badan Pertanahan Nasional Nomor : 14/HGU/1991 tentang Pemberian Hak Guna Usaha Atas Nama PT. Mutiara Agam.

Pada keputusan ini disebutkan langkahlangkah dan mekanisme yang telah dilakukan sebelum hak guna usaha ini keluar, antara lain :

a. PT. Mutiara Agam adalah badan hukum yang telah memenuhi persyaratan memperoleh hak guna usaha atas tanah negara, menurut peta situasi khusus tanggal 20 Mei 1990 nomor 01/1990 seluas 8.625 hektare berasal dari tanah ulayat nagari dan tanah kawasan hutan, yang telah dilepaskan berdasarkan Surat Penyerahan Tanah Ulayat Nagari tanggal 19 agustus 1983 dan surat Keputusan Menteri Kehutanan RI tanggal 25 Agustus 1987 Nomor 258/KptsII/1987, terletak di desa Ujung Labung, Masang, Labuhan, Muara Putus dan Subang-Subang, Kecamatan Tanjung Mutiara, Kabupaten Agam Provinsi Sumatera Barat.

b. Tanah tersebut dikuasai oleh pemohon (PT. Mutiara Agam) berdasarkan Surat Keputusan Gubernur Kepala Daerah Tingkat I Sumatera Barat tanggal 19 Agustus 1986 Nomor SK. 525.26-275-1986 Jo. Tanggal 21 Januari 1988 Nomor 14/Sekr/BKPMD 1988, tentang izin Pencadangan tanah serta izin lokasi dan pembebasan tanah kepada PT. Mutiara Agam atas tanah seluas 10.075 hektare untuk usaha perkebunan kelapa sawit.

c. Menteri Pertanian RI dalam suratnya tanggal 9 Juli 1984 Nomor KB. 320/457/Mentan/VII/1984 telah memberikan persetujuan prinsip kepada PT. Mutiara Agam untuk mengusahakan komoditi kelapa sawit diatas tanah seluas 10.000 hektare.

d. Panitia Pemeriksaan Tanah (Panitia B) Provinsi Sumatera Barat dalam risalahnya tanggal 20 september 1988 jo. Tanggal 9
Mei 1990 pada prinsipnya dapat menyetujui permohonan Hak Guna Usaha PT. Mutiara Agam atas tanah seluas 8.625 hektarte.

e. Gubernur Kepala Daerah Tk. I Sumatera Barat dalam surat pengantarnya tanggal 8 September 1990 Nomor 540.1.738/HATBPN/1990 mengusulkan agar kepada PT. Mutiara Agam dapat diberikan Hak Guna Usaha atas tanah seluas 8.625 hektare untuk usaha perkebunan kelapa sawit.

f. Team Pertimbangan Hak Guna Usaha Perkebunan Besar dalam suratnya tanggal 15 Juni 1991 Nomor 08/Tim HGU/Pert/91, telah menyampaikan pertimbangan kepada Kepala Badan Pertanahan Nasional agar permohonan PT. Mutiara Agam dapat disetujui untuk dikabulkan, dengan diberikan Hak Guna Usaha selama 35 tahun, atas tanah seluas 8.625 hektare untuk diusahakan dengan tanaman kelapa sawit.

g. Berdasarkan hal-hal yang tersebut di atas dan mengingat fungsi perkebunan sebagai penghasil devisa negara serta sesuai dengan kebijaksanaan pemerintah dalam bidang ekonomi dan pembangunan, maka dipandang telah memenuhi syarat-syarat untuk memberikan Hak Guna Usaha atas tanah negara tersebut kepada PT. Mutiara Agam dalam hal ini pemohon.

Pada keputusan ini, pemberian hak guna usaha tersebut disertai syarat dan ketentuan sebagai berikut :

a. Penerima Hak Guna Usaha tunduk pada dan diwajibkan untuk memenuhi ketentuanketentuan Peraturan Menteri Pertanian dan Agraria Nomor 11 tahun 1962 jo. Nomor 2 tahun 1964 yang telah diubah dengan Peraturan Bersama Menteri Pertanian tanggal 20 Agustus 1969 nomor 8 tahun 1969 dan Nomor 2/Pert/OP/8/1969.

b. Luas dan batas-batas yang pasti dari tanah yang diberikan dengan Hak Guna Usaha ini adalah ditentukan berdasarkan hasil pengukuran dari Instansi Badan Pertnahan Nasional sebagaimana tersebut dalam gambar situasi khusus tanggal 20 Mei 1990 Nomor 01/1990. 
c. Apabila didalam areal yang diberikan dengan hak guna usaha ini ternyata masih terdapat pendudukan/penggarapan rakyat secara menetap dan dilindungi UndangUndang serta belum mendapat penyelesaian, maka menjadi kewajiban dan tanggungjawab sepenuhnya dari penerima hak untuk menyelesaikan dengan sebaikbaiknya menurut ketentuan peraturan yang berlaku.

d. Tanah yang diberikan dengan hak guna usaha ini harus dipergunakan untuk usaha perkebunan dengan tanaman kelapa sawit.

e. Setiap perubahan penyelenggaraan perusahaan, peruntukan dan segala bentuk perbuatan yang bermaksud untuk memindahkan hak guna usaha atas tanah perkebunan tersebut diperlukan izin terlebih dahulu dari Kepala Badan Pertanahan Nasional.

f. Penerima hak guna usaha wajib melangsungkan dan memelihara menghindarkan terlantarnya pengusahaan/kelestarian tanah tersebut, serta menjaga dari setiap kemungkinan upaya-upaya penggarapan oleh pihak ketiga.

g. Hak guna usaha ini mulai berlaku sejak tanggal didaftarkan pada kantor pertanahan kabupaten yang bersangkutan dan akan berakhir pada tanggal 31 Desember 2026.

h. Hak guna usaha ini akan diperpanjang dengan jangka waktu paling lama 25 tahun, apabila pada waktunya kelak menurut penilaian pemerintah tanah perkebunan dengan hak guna usaha ini telah diusahakan dengan baik dan memenuhi persyaratanpersyaratan yang ditentukan.

Dapat diurutkan mengenai mekanisme peralihan tanah ulayat Nagari Tiku Limo Jorong kepada PT. Mutiara Agam antara lain :

a. Pada tahun 1983, Nagari Tiku Limo Jorong mempersilahkan kepada investor untuk mengelola tanah yang ada di Nagari Tiku Limo Jorong, guna memajukan daerah tersebut karena pada masa itu Nagari Tiku Limo Jorong merupakan daerah terisolir, dan terdapat suatu kesepamahan kepada PT.
Mutiara Agam, ninik mamak Nagari Tiku Limo Jorong pun melakukan penyerahan tanah ulayat nagari tersebut kepada PT. Mutiara Agam dengan melalui Surat Penyerahan Tanah Ulayat Nagari tanggal 19 agustus 1983 dan pelepasan tanah kawasan hutan melalui surat Keputusan Menteri Kehutanan RI tanggal 25 Agustus 1987 Nomor 258/Kpts-II/1987.

b. Tanah tersebut dikuasai oleh pemohon (PT. Mutiara Agam) berdasarkan Surat Keputusan Gubernur Kepala Daerah Tingkat I Sumatera Barat tanggal 19 Agustus 1986 Nomor SK. 525.26-275-1986 Jo. Tanggal 21 Januari 1988 Nomor 14/Sekr/BKPMD 1988, tentang izin Pencadangan tanah serta izin lokasi dan pembebasan tanah kepada PT. Mutiara Agam atas tanah seluas 10.075 hektare untuk usaha perkebunan kelapa sawit.

c. Kemudian Menteri Pertanian juga memberikan persetujuan prinsip kepada PT. Mutiara Agam melalui Surat Menteri Pertanian RI Nomor KB.320/457/Mentan/VII/1984.

d. Dibentuklah Panitia yang dinamakan Panitia Pemeriksaan Tanah (Panitia B) Provinsi Sumatera Barat dalam risalahnya tanggal 20 september 1988 jo. Tanggal 9 Mei 1990 pada prinsipnya dapat menyetujui permohonan Hak Guna Usaha PT. Mutiara Agam atas tanah seluas 8.625 hektarte.

e. Team Pertimbangan Hak Guna Usaha Perkebunan Besar dalam suratnya tanggal 15 Juni 1991 Nomor 08/Tim HGU/Pert/91, telah menyampaikan pertimbangan kepada Kepala Badan Pertanahan Nasional agar permohonan PT. Mutiara Agam dapat disetujui untuk dikabulkan, dengan diberikan Hak Guna Usaha selama 35 tahun, atas tanah seluas 8.625 hektare untuk diusahakan dengan tanaman kelapa sawit.

f. Kemudian keluarlah Keputusan Kepala Badan Pertanahan Nasional Nomor : 14/HGU/1991 tentang Pemberian Hak Guna Usaha Atas Nama PT. Mutiara Agam. 


\section{B. Manfaat yang Dapat Diperoleh Oleh Si Pemilik Tanah Ulaya}

Manfaat yang diperoleh oleh masyarakat

Nagari Tiku Limo Jorong sebagaimana yang disebutkan oleh Bapak Agusmaidi bahwa diberikan kompensasi sebagaimana berdasarkan peraturan pemerintah yaitu peraturan menteri perkebunan, perusahaan tersebut wajib membangun plasma, yang saat ini luas nya 3.000 hektare plasma. Perkebunan rakyat 3.000 hektare ini dari PT. Mutiara Agam dengan bantuan teknis, yang dikelola oleh masyarakat sekitar. Dan juga terdapat perjanjian-perjanjian tidak tertulis lainnya pada masa itu, seperti adanya penyerahan uang kepada beberapa orang tertentu, serta diperbolehkannya untuk bekerja di PT. Mutiara Agam.

Disebutkan pada Undang-Undang Nomor 39 tahun 2014 tentang perkebunan pada pasal 58 ayat 1, perusahaan perkebunan yang memiliki izin usaha perkebunan atau izin usaha perkebunan untuk budi daya wajib memfasilitasi pembangunan kebun masyarakat sekitar paling rendah seluas $20 \%$ (dua puluh perseratus) dari total luas areal kebun yang diusahakan oleh perusahaan perkebunan.

Lebih lanjut, Kepala Badan Pertanahan Nasional Sofyan Djalil mengingatkan kalangan pengusaha kelapa sawit agar membangun perkebunan plasma untuk masyarakat. Ia menyatakan, Kewajiban plasma ini harus ditegaskan agar kesenjangan ekonomi tidak melebar. Bagi yang belum mengalokasikan plasma agar segera dilaksanakan. Setiap pengusaha perkebunan diharuskan membangun plasma seluas $20 \%$ dari luas konsesi hak guna usaha. Karena itu, Sofyan memastikan BPN siap membantu pengusaha jika mengalami kendala dalam sertifikasi lahan. Pola kemitraan plasma merupakan amanat dari Undang-Undang No. 18 tahun 2004 tentang Perkebunan.

Pola kemitraan adalah suatu bentuk kerja sama pembangunan dan pengembangan perkebunan dengan menggunakan perkebunan besar sebagai perusahaan inti yang membimbing perkebunan rakyat disekitarnya sebagai plasma melalui lembaga koperasi dalam suatu sistem kerjasama yang saling menguntungkan, saling mengisi, utuh dan berkesinambungan. Hak-hak petani peserta :

1. Memperoleh bimbingan teknis budidaya tanaman dan non teknis dari Dinas yang membidangi

perkebunandanperusahaan sebagai perusahaan inti. Bimbingan dapat teknis budidaya tanaman kelapa sawit dan non teknis organisasi (kelembagaan) sampai dengan manajemen ekonomi rumah tangga petani.

2. Memperoleh kredit investasi perkebunan pengembangan kebun plasma dan subsidi bunga kredit dari pemerintah (apabila pendanaan dari pemerintah sudah ada, apabila belum dengan bunga komersiil).

3. Mendapatkan kesempatan bekerja di kebun inti dan kebun plasma, sebagai tenaga kerja dengan status PTT, sesuai dengan formasi. Apabila yang bersangkutan promosi sebagai karyawan tetap s/d staf tidak dibenarkan lagi sebagai petani peserta plasma (sesuai peraturan perusahaan, karyawan tetap tidak dibenarkan memiliki plasma).

4. Memperoleh sertifikat lahan kebun plasma secara bersama-sama dalam satu desa atau kelompok tani dalam bentuk sertifikat hak guna usaha.

5. Membentuk kelompok tani, yang selanjutnya berkembang menjadi lembaga koperasi, dengan dibimbing perusahaan inti. Koperasi dapat melakukan pengawasan pembangunan dan perawatan kebun, produksi (panen), perlakukan grading, pemupukan, dan pengawasan pekerjaan lainnya di lapangan.

Mitra usaha berkewajiban :

1. Memiliki perkebunan dan atau fasilitas pengelola yang dapat menampung hasil perkebunan

2. Melaksanakan pengembangan perkebunan petani peserta, sesuai dengan petunjuk operasional dan standar teknis yang ditetapkan oleh Departemen Pertanian Direktur Jenderal Perkebunan

3. Bertindak sebagai avalis untuk pembiayaan pengembangan perkebunan 
4. Mengikut sertakan perkebunan secara aktif dalam proses pengembangan perkebunan.

5. Membina secara teknis dan management para pekebun agar mampu mengusahakan kebunnya baik masa pengembangan maupun selama tanaman menghasilkan serta memfasilitasi peremajaan tanaman

6. Membeli hasil kebun dengan harga sesuai dengan ketentuan yang berlaku dan atau kesepakatan bersama antara mitra usaha dan pekebun

7. Menyelenggarakan proses pelaksanaan dan pengembalian kredit perkebunan.

Masyarakat sekitar yang penulis wawancarai, yaitu bapak Aris mengatakan bahwa ia menerima kemitraan plasma ini satu kali dalam satu tahun. Hasil yang diterima berdasarkan banyaknya hasil panen dari kebun plasma masyarakat tersebut. Diberikan berdasarkan satu kepala keluarga, sebesar Rp. 10.000.000 atau apabila hasil panen sedikit ia menerima sebesar Rp. 5.000.000. Warga lainnya yaitu bapak Zal juga menyatakan hal yang sama seperti bapak Aris tadi, ia menerima satu kali dalam satu tahun yang biasanya sebesar Rp. 10.000.000. Menurut kedua orang warga ini, pada umumnya semua masyarakat pribumi Nagari Tiku Limo Jorong menerima hasil dari kemitraan plasma tersebut.

Ditambahkan lagi oleh bapak Amsurman dt. Nan kodorajo perwakilan dari PT. Mutiara Agam, pada saat itu penyerahan tanahnya dilakukan tanpa melakukan ganti rugi, dengan tujuan dapat memajukan daerah Nagari Tiku Limo Jorong, tetapi ada juga beberapa perjanjian yang tidak tertulis seperti beberapa warga diperbolehkan untuk bekerja di PT. Mutiara Agam. Serta dibuatkan plasma kepada masyarakat sesuai dengan peraturan pemerintah yang telah ada, dengan luas 3.000 hektare.

Manfaat yang didapat oleh pemilik tanah ulayat ini yang merupakan tanah ulayat nagari, dan dikuasai oleh Nagari Tiku Limo Jorong bisa terlihat dari meningkatnya perekonomian warga dengan adanya PT. Mutiara Agam, ditambah dengan hadirnya kemitraan plasma. Kemudian warga mendapatkan lapangan pekerjaan, serta akses menuju Nagari Tiku Limo Jorong lebih lancar dan mudah dengan adanya pembangunan jalan beraspal, sehingga Nagari Tiku Limo Jorong tidak menjadi daerah terisolir lagi.

\section{Kedudukan Tanah Ulayat Disaat Penggunaan Hak Guna Usaha dan Setalah Berakhirnya Hak Guna Usaha}

Tanah yang saat ini digunakan oleh PT. Mutiara Agam sebelumnya merupakan tanah ulayat nagari Tiku Limo Jorong, dan pada saat penggunaan hak guna usaha saat ini tidak berstatus sebagai tanah ulayat nagari, yaitu sudah menjadi hak guna usaha. Hak guna usaha ini nantinya akan berakhir pada tanggal 31 desember 2026 seperti yang tercantum dalam Keputusan Kepala Badan Pertanahan Nasional Nomor : 14/HGU/1991 Tentang Pemberian Hak Guna Usaha Atas Nama PT. Mutiara Agam. Bapak Amsurman dt. Nan Kodorajo perwakilan dari PT. Mutiara Agam menyatakan, mengingat berdasarkan peraturan yang ada, tanah ini apabila sudah berakhir masa hak guna usaha nya akan kembali diambil alih oleh pemerintah, tetapi nanti juga akan dilakukan semacam mufakat kembali dengan ninik mamak dan masyarakat Nagari Tiku Limo Jorong, apakah akan diperpanjang kembali hak guna usaha tersebut atau tidak. Kedudukan tanah tersebut sekarang dalam hak guna usaha sesuai berdasarkan keputusan tahun 1991, tidak dalam bentuk ulayat.

Sesuai yang disebutkan dalam Peraturan Pemerintah Nomor 40 Tahun 1996 tentang Hak Guna Usaha, Hak Guna Bangunan, dan Hak Pakai Atas Tanah pada pasal 12 ayat (1) huruf g dan h yang berbunyi :

g. menyerahkan kembali tanah yang diberikan dengan hak guna usaha kepada negara sesudah hak guna usaha tersbut hapus.

h. menyerahkan sertifikat hak guna usaha yang telah hapus kepada Kepala Kantor Pertanahan.

Disebutkan dalam Pasal 26 Peraturan Menteri Negara Agraria/Kepala Badan Pertanahan Nasional Nomor 9 tahun 1999 tentang Tata Cara Pemberian dan Pembatalan Hak Atas Tanah Negara dan Hak Pengelolaan, 
sesudah jangka waktu hak guna usaha atau perpanjangannya berakhir kepada pemegang hak dapat diberikan pembaharuan hak guna usaha diatas tanah yang sama.

Pendapat berbeda disampaikan oleh Bapak Agusmaidi Sidi Bandaro selaku sekretaris Kerapatan Adat Nagari menyatakan, bahwa kami merasa tidak ada menyerahkan tanah ini ke pemerintah, penyerahannya langsung diberikan kepada PT. Mutiara Agam dari Nagari Tiku Limo Jorong, jadi tanah ini nanti nya memang kembali ke bentuk semula yaitu tanah ulayat nagari. Mengenai apakah akan dilakukan perpanjangan atau tidak atas hak guna usaha oleh PT. Mutiara Agam nantinya akan dilakukan perundingan, apabila merasa cocok kembali tentu nya akan diperpanjang kembali, pada prinsipnya masyarakat Nagari Tiku Limo Jorong memang menginginkan untuk diperpanjang, karena di sisi lain masyarakat merasakan ada manfaat nya untuk masyarakat Nagari Tiku Limo Jorong itu sendiri.

Bapak Agusmaidi menyatakan juga berpegang kepada Peraturan Daerah Provinsi Sumatera Barat Nomor 6 Tahun 2008 Tentang Tanah Ulayat dan Pemanfaatannya Pasal 14 ayat (2), yang berbunyi :

(1) Terhadap tanah ulayat yang terdaftar dengan hak tertentu berakhir masa berlakunya dapat diperpanjang, berdasarkan persetujuan dari penguasa dan atau pemilik tanah ulayat semula;

(2) Terhadap tanah ulayat yang terdaftar sebagaimana dimaksud pada ayat (1) berakhir, maka pengaturan pemanfaatan tanah selanjutnya dilaksanakan oleh Pemerintah Kabupaten/Kota untuk diserahkan kepada penguasa dan atau pemilik tanah ulayat semula.

\section{Kesimpulan}

Berdasarkan hasil penelitian dan pembahasan dapat disimpulkan bahwa :

1. Tanah yang dipergunakan oleh PT. Mutiara Agam sebagai hak guna usaha ini dulunya merupakan tanah ulayat nagari Tiku Limo Jorong. Berawal pada tahun 1983 dengan cara penyerahan tanah hanya melalui Nagari Tiku Limo jorong langsung kepada PT. Mutiara Agam, oleh ninik mamak dengan Surat Pernyataan Penyerahan Tanah Ulayat Nagari tanggal 19 Agustus 1983. Kemudian barulah mulai berlaku hak guna usaha dari tahun 1991 dan berakhir pada tanggal 31 desember 2026, sesuai dengan jangka waktu hak guna usaha yaitu 35 tahun. Tercantum di dalam Keputusan Kepala Badan Pertanahan Nasional Nomor : 14/HGU/1991 tentang Pemberian Hak Guna Usaha Atas Nama PT. Mutiara Agam.

2. Manfaat yang diperoleh oleh masyarakat Nagari Tiku Limo Jorong saat ini terdapat 3.000 hektare kemitraan plasma yang diberikan oleh PT. Mutiara Agam kepada masyarakat Nagari Tiku Limo Jorong dan dikelola oleh masyarakat. Manfaat lainnya yaitu dengan adanya PT. Mutiara Agam ini perekonomian masyarakat Nagari Tiku Limo Jorong menjadi meningkat karena terbukanya lapangan pekerjaan, beberapa warga sekitar dapat bekerja di PT. Mutiara Agam, serta akses jalan menuju Nagari Tiku Limo Jorong menjadi lancar, yang mana nagari ini dulunya adalah daerah terisolir.

3. Kedudukan tanah yang saat ini dipergunakan oleh PT. Mutiara Agam adalah hak guna usaha dan apabila sudah berakhir maka akan kembali menjadi bentuk semula namun tentunya akan dilakukan perundingan antara PT. Mutiara Agam beserta pihak Nagari Tiku Limo Jorong, apakah nantinya akan tetap dilanjutkan. Berdasarkan keterangan sekretaris kerapatan adat nagari Tiku Limo Jorong, pada prinsipnya masyarakat ingin memperpanjang kembali apabila nantinya sudah habis masa waktunya.

\section{A. Saran}

Adapun saran-saran yang dapat diberikan oleh penulis : 
1. PT. Mutiara Agam dapat melakukan kewajiban-kewajibannya sebagai pemilik hak guna usaha, seperti yang telah disebutkan pada Keputusan Kepala Badan Pertanahan Nasional Nomor : 14/HGU/1991 tentang Pemberian Hak Guna Usaha Atas Nama PT. Mutiara Agam. Dan peraturan perundangundangan lainnya yang mengatur mengenai hak guna usaha.

2. Masyarakat dapat memanfaatkan kemitraan plasma yang diberikan oleh PT. Mutiara Agam sebaik-baiknya sehingga dapat menghasilkan hasil yang bisa lebih memajukan perekonomian masyarakat Nagari Tiku Limo Jorong, sehingga dapat merasakan manfaat dari adanya perusahaan tersebut di daerah mereka.. Dan untuk perusahaan dapat memberikan pendampingan kepada perusahaan plasma sebagai perusahaan inti.

3. Sebaiknya dilakukan perundingan kembali oleh pihak PT. Mutiara Agam dan Nagari Tiku Limo Jorong. Karena terlihat disini perbedaan pendapat antara PT. Mutiara Agam dan Nagari Tiku Limo Jorong, bahwa apabila nantinya hak guna usaha ini sudah berakhir. Pihak PT. Mutiara Agam menyebutkan bahwa tanah tersebut akan diambil alih oleh pemerintah dikarenakan statusnya sekarang hak guna usaha, berdasarkan peraturan yang ada sebelum menjadi hak guna usaha tanah tersebut dikuasai oleh negara. Sedangkan pihak Nagari Tiku Limo Jorong beranggapan tidak pernah merasa menyerahkan tanah tersebut kepada pemerintah, penyerahannya saat itu langsung kepada PT. Mutiara Agam sehingga tanah tersebut nantinya akan kembali ke bentuk semula yaitu tanah ulayat nagari Tiku Limo Jorong.

\section{DAFTAR PUSTAKA}

\section{A. Buku}

Ali,Zainduddin, 2009, Metode Penelitian Hukum, Sinar grafika, Jakarta

Harsono,Boedi, 2008, Hukum Agraria Indonesia : Sejarah Pembentukan Undang-Undang Pokok Agraria, Isi, da Pelaksanaannya, Djambatan, Jakarta.

Sarkawi , 2014, Hukum Pembebasan Tanah Hak Milik Adat Untuk Pembangunan Kepentingan Umum, Graha Ilmu, Yogyakarta

Sutedi, Adrian, 2007, Implementasi Prinsip Kepentingan Umum Dalam Pengadaan Tanah Untuk Pembangunan, Sinar Grafika, Jakarta

Syarifuddi, Amir, 1984, Pelaksanaan Hukum Kewarisan Islam Dalam Lingkungan Hukum Adat Minangkabau, Gunung Agung, Jakarta

\section{B. Peraturan Perundang-Undangan}

Undang-Undang Nomor 5 tahun 1960 tentang Peraturan Dasar Pokok-Pokok

Agraria

Perda Provinsi Sumatera Barat no. 16 tahun 2008 tentang Tanah Ulayat

Peraturan Daerah Sumatera Barat No.9 Tahun 2000 tentang Pemerintahan

Nagari

Peraturan Pemerintah Nomor 40 Tahun 1996 tentang Hak Guna Usaha, Hak

Guna Bangunan, dan Hak pakai atas tanah

Permendagri Nomor 15 Tahun 1975 tentang Ketentuan-Ketentuan Mengenai

Tata Cara Pembebasan Tanah.

Undang-Undang No. 26 tahun 2007 tentang Penataan ruang 
Peraturan Menteri Negara Agraria/Kepala Badan Pertanahan Nasional nomor 3 tahun 1999.

Peraturan Pemerintah nomor 24 tahun 1997 tentang Pendaftaran Tanah

Keputusan Menteri Agraria/Badan Pertanahan Nasional nomor 5 tahun 1998 tentang Perubahan HGB atau Hak Pakai atas Tanah Untuk Rumah

Tinggal yang Dibebani Hak Tanggungan Menjadi Hak Milik.

Keputusan Kepala Badan Pertanahan Nasional Nomor : 14/HGU/1991 tentang Pemberian Hak Guna Usaha Atas Nama PT. Mutiara Agam

Surat Keputusan Menteri Kehutanan RI nomor 258/Kpts-II/1987

Surat Keputusan Gubernur Kepala Daerah Tingkat I Sumatera Barat Nomor

SK.525.26-275-1986 jo. Nomor 14/Sekr/BKPMD 1988 tentang izin

pencadangan tanah serta izin lokasi dan pembebasan tanah kepada PT.

Mutiara Agam

Surat Menteri Pertanian RI Nomor KB.320/457/Mentan/VII/1984

Surat Persetujuan Ketua Badan Koordinasi Penanaman Modal Nomor 124/I/PMDN/1986 jo. Nomor 336/III/PMDN/1991

Surat Kepala Dinas Perkebunan Provinsi Sumatera Barat Nomor 525.30/784/525.3/88

Surat Pengantar Gubernur Kepala Daerah Tingkat I Sumatera Barat Nomor 540.1.738/HAT-BPN/1990

\section{C.Website}

http://www.hukumonline.com/klinik/detail/c 16522/tanah-ulayat

http://industri.bisnis.com/read/20170202/99/ 625318/sofyan-djalil-pengusaha-sawit-

wajib-bangun-kebun-plasma https://www.slideshare.net/bundatea/kebunplasma-pola-kemitraan http://www.agamkab.go.id/?agam=profil 